\title{
Anti-Fusarium moniliforme Activity and Fumonisin Biodegradation by Corn and Silage Microflora
}

\author{
Simone B. Camilo ${ }^{1}$, Carlos José Ono ${ }^{1}$, Yoshio Ueno ${ }^{2}$ and Elisa Y. Hirooka*1 \\ ${ }^{1}$ Depto Tecnologia de Alimentos e Medicamentos, Universidade Estadual de Londrina, Caixa Postal 6001, \\ CEP.86051-970-Londrina-PR, Brazil. ${ }^{2}$ Science University of Tokyo, Faculty of Pharmaceutical Sciences, Ichigaya, \\ Shinjiku-ku, Tokyo 162, Japan.
}

\begin{abstract}
Studies were carried out to isolate microorganisms from corn and silage screened for their ability to inhibit $\mathrm{F}$. moniliforme growth (strain 113F) in association with fumonisin detoxification. Among 150 isolates four Grampositive bacilli and one yeast with inhibitory activity were selected. The inhibition zone ranged from 50 to $72.5 \mathrm{~mm}$ using cultures, and from 25 to $52.5 \mathrm{~mm}$ for crude alcoholic extract. The isolates S9, S10, S69 (sporulated bacilli) and SE3071 (yeast) degraded 43, 48, 83 and 57\% of the initial FB $F_{1}$ concentration, respectively. The pH increased gradually in the medium during incubation for biodegradation process.
\end{abstract}

Key words: Fusarium moniliforme, fumonisin, biodegradation

\section{INTRODUCTION}

Fumonisins belong to a mycotoxin group produced by Fusarium moniliforme on corn (Marasas, et al., 1984). The compound is propane1,2,3- tricarboxylic acid of 2-amino 12,16-dimetil polihydroxy eicosane diesters, with $\mathrm{C}_{14}$ and $\mathrm{C}_{15}$ esterified by hydroxyl of the carboxylic acid (Bezuidenhout et al., 1988). Although the literature describes eight fumonisins, only $\mathrm{FB}_{1}$, $\mathrm{FB}_{2}$ and $\mathrm{FB}_{3}$ have been detected naturally in corn (Gelderblom et al., 1988; Cawood et al., 1991; (Sydenham et al., 1991; Thiel et al., 1992). Characterized as tricarboxylated amino polyalcohol, similar to esfingosins, they cause toxicity, inducing cerebral lesion-LEME in horses, lung edema in swines, imunodepression in poultry and hepatic carcinogenicity in rats (Marasas et al., 1988; Gelderblom et al., 1991; Norred,1993). Recent works have also reported nephrosis, thrombosis, atherosclerosis and toxicosis in other animals (Norred, 1993; Galvano et al.,1997). In humans, the natural occurrence was associated with oesophageal cancer in South Africa and China (Sydenham et al., 1990; Rheder et al., 1992; Wang et al., 1995).
The removal of fine corn particles reduces $\mathrm{FB}_{1}$ contamination from $26 \%$ to $69 \%$, but normal drying or heating treatment is ineffective for total fumonisin removal (Sydenham et al., 1994). The use of $\mathrm{Ca}(\mathrm{OH})_{2}$ and/or $\mathrm{H}_{2} \mathrm{O}_{2}$ and $\mathrm{NaHCO}_{3}$ reduced respectively, $81 \%$ and $100 \%$ of $\mathrm{FB}_{1}$ (Park et al., 1997). A promising procedure is the adsorption method that uses multisequestring agents, like aluminum silicates and sepiolites, with recent inclusion of activated carbon, capable of adsorbing $100 \%$ of $\mathrm{AFB}_{1}$ and $\mathrm{FB}_{1}$ (Galvano et al., 1997). However, chemical agents affect functional properties of the grain, while adsorbents could affect nutritional components.

Considering the worldwide contamination of corn by $F$. moniliforme in the field, and that fumonisins are produced in the pre-drying step of harvested corn (Hirooka et al., 1996; Ono et al., 1998), one promising option could be the control by using antagonists microorganisms isolated directly from plant microbiota (Motomura et al., 1996). In this work, the effectiveness of microorganisms isolated from the natural habitat of corn and silage, for the control of $F$. moniliforme and fumonisins degradation, without causing drastic alterations in the ecosystem, were analyzed.

\footnotetext{
* Author for correspondence
} 


\section{MATERIAL AND METHODS}

Microorganisms: The reference microorganism was $F$. moniliforme strain $113 \mathrm{~F}$, isolated from feed involved in animal intoxication. The initial productivity reached $54.21 \mathrm{mg} / \mathrm{g}$ and $87.31 \mathrm{mg} / \mathrm{g}$ of $\mathrm{FB}_{1}$ and $\mathrm{FB}_{2}$, respectively (Hirooka et al., 1996). The antagonic microorganisms were isolated from corn and silage obtained from Paraná State (north region), Brazil. The screening was conducted as described by Motomura (1995) and plated in Man, Rogosa \& Sharpe (MRS) medium (Oliveira, 1995). The antagonists belonging to the Bacillus sp. group were cultivated in brain heart infusion (BHI) broth and the yeasts in malt extract broth. The cultures were maintained at $4^{\circ} \mathrm{C}$.

Screening of antagonic microorganisms: The silage and corn isolates were submitted to antibiogram, using the pour plate technique in potato dextrose agar - PDA inoculated with $10^{6}$ propagules $/ \mathrm{mL}$ of $F$. moniliforme (Motomura, 1995). After solidification, $0.1 \mathrm{~mL}$ of antagonist culture, or crude alcoholic extract previously prepared with ethanol and then concentrated 5 times at $45^{\circ} \mathrm{C}$, was applied into the center of the agar plate (Motomura et al., 1996). The plates were then incubated at $25^{\circ} \mathrm{C}$ for 7 days and the inhibition zone were measured.

Fumonisin production in corn culture: The corn culture was obtained by inoculating $2 \mathrm{~mL}\left(10^{6}\right.$ spores $/ \mathrm{mL}$ ) of $F$. moniliforme $113 \mathrm{~F}$ on the surface of $100 \mathrm{~g}$ of ground corn, previously humidified with $100 \mathrm{~mL}$ of distilled water and autoclaved for $30 \mathrm{~min}$. After incubation at $25^{\circ} \mathrm{C}$ for 30 days, the culture was solvent treated as described below and $\mathrm{FB}_{1}$ analyzed by HPLC (Weibking et al., 1993).

Preparation of material for fumonisins degradation assay: Cleaning of the crude culture was conducted according to Weibking et al. (1993), using 400mL of acetone:chloroform 75:25 (V/V), by overnight agitation of the sample at 180 $\mathrm{rpm}$ at $25^{\circ} \mathrm{C}$. The extracted material was filtered through Whatman $n^{\circ} 1$ filter paper, and the culture residue cleaned again with acetone:chloroform 75:25. The solid residue was evaporated in a air circulation chamber at $40^{\circ} \mathrm{C}$ for 48 hours, ground and stored at $-7^{\circ} \mathrm{C}$.

For the fumonisin degradation assay, $0.015 \mathrm{M}$ phosphate saline buffer - PBS at $\mathrm{pH} 7.0$ was added to the dried corn culture in a $10: 1(\mathrm{~V} / \mathrm{V})$ ratio. The suspended material was extracted at $180 \mathrm{rpm}, 25^{\circ}$ $\mathrm{C}$ for $30 \mathrm{~min}$, centrifuged at $10,000 \mathrm{xg}$ and filtered through Whatman $n^{\circ} 1$ filter paper.

Fumonisins degradation by selected microorganisms: The five microorganisms that showed higher anti-F.moniliforme activity were cultivated in $200 \mathrm{~mL}$ of BHI broth (Bacillus spp.) at $35^{\circ} \mathrm{C}$, or in malt extract broth (yeasts) at $25^{\circ} \mathrm{C}$, respectively. One $\mathrm{mL}$ of standardized culture of antagonists (absorbance 0.3 at $600 \mathrm{~nm}$ ) was transferred to tubes containing $4 \mathrm{~mL}$ of $\mathrm{BHI}$ or malt extract broth amended with $4 \mathrm{~mL}$ of $F$. moniliforme culture suspension in PBS with known concentration of $\mathrm{FB}_{1}$. The assay for each microorganism consisted of five determinations made in triplicate, incubated at $25^{\circ} \mathrm{C}$ (yeast) or 35 ${ }^{\circ} \mathrm{C}$ (Bacillus sp.). Every two days, during 15 days, the culture was interrupted for fumonisin analysis, centrifuged at $10,000 \mathrm{xg}$, and filtered through a Whatman $n^{\circ} 1$ filter paper.

The analyses consisted of $\mathrm{pH}$ determination, along with fumonisin quantification by HPLC. The remaining $\mathrm{FB}_{1}$ was calculated as $\mu \mathrm{g} / \mathrm{g}$, considering that the treated corn culture contained $230 \mu \mathrm{g} / \mathrm{g}$ of $\mathrm{FB}_{1}$. The control consisted in the culture medium added with treated corn culture, but without antagonist.

Determination of fumonisins by HPLC: The fumonisins were determined using the method of Shephard et al. (1990), modified by Ueno et al. (1993). One $\mathrm{mL}$ of the culture filtrate was clarified in Sep Pak Accell Plus QMA Cartridges, previously conditioned with $6 \mathrm{~mL}$ methanol: water at $3: 1(\mathrm{~V} / \mathrm{V})$ ratio, followed by elution with $3 \mathrm{~mL}$ methanol. The toxin was eluted with $10 \mathrm{~mL}$ ethanol with $0.5 \%$ acetic acid, evaporated at $40^{\circ} \mathrm{C}$ and re-suspended in $1 \mathrm{~mL}$ of methanol. After drying, $2 \mathrm{~mL}$ of methanol-water (3:1) was added and evaporated under nitrogen at $50^{\circ} \mathrm{C}$. For analysis, it was suspended in $800 \mu \mathrm{L}$ of methanolwater (3:1) and a $200 \mu \mathrm{L}$ aliquot was dried under nitrogen. After derivatization with $200 \mu \mathrm{L}$ of ortho-phtaldehyde (40mg orthophtaldehyde, $1 \mathrm{~mL}$ methanol, $5 \mathrm{~mL} 0.1 \mathrm{M}$ sodium borate and $50 \mu \mathrm{L} 2-$ mercaptoethanol), the analysis was carried out in isocratic HPLC (Shimadzu LC-10AD) using reverse phase $\mathrm{C}_{18}$ column $(250 \times 4.6 \mathrm{~mm})$, with $5 \mu \mathrm{m}$ of Supelco's nucleosil. The mobile phase consisted of methanol-sodium phosphate $0.1 \mathrm{M}$ (80:20) adjusted to $\mathrm{pH}$ 3.3. The equipment was conditioned to a flow of $1 \mathrm{~mL} / \mathrm{min}$. with 
wavelength of excitation and emission of $335 \mathrm{~nm}$ and 450nm (Shimadzu F 535), respectively.

\section{RESULTS AND DISCUSSION}

A total of 150 microorganisms were isolated from corn and silage using MRS culture medium. Submitting the same isolates to antibiogram test (Motomura, 1995) against F. moniliforme 113F, inhibitory activity was detected in 28 isolates. The antagonists were identified as 13 yeasts and 15 bacteria, with predominance of bacilli over cocci and lactic bacteria. Similar data were obtained in a previous work with corn and soil samples (Motomura et al., 1996). This predominance could be explained by the use of surface samples of silage, which favors development of aerobic groups, to the detriment of lactic bacteria. The antimicrobial activity on the silage surface may be important in natural biocontrol of mycotoxigenic fungal proliferation, which is favored by aerobiosis.

Four Bacillus sp. and one yeast, designated as S1, S9, S10, S69 and SE3071, respectively, showed highest anti-F.moniliforme activity (Table 1 ). The inhibition zone using whole culture ranged from 50 to $72.5 \mathrm{~mm}$, compared to the crude extract of the same cultures which ranged from 25 to
$52.5 \mathrm{~mm}$, indicating loss of inhibitory activity during the concentration of the alcoholic extract by heating at $45^{\circ} \mathrm{C}$. Higher losses occurred with strains S1, S9, SE3071, S69 and S10 in a decreasing order. The instability of yeast product may be due to the expression of antagonistic activities as a product of the "Killer" factor, constituted by toxic peptic compounds (Walker et al., 1995; Kashiwagi et al., 1997).

Besides the anti-F.moniliforme effect, an ideal condition would be if the same microorganism was able to degrade the toxic fungal metabolites. Tables 2 and 3 contain data on the activity regarding $\mathrm{FB}_{1}$ degradation, along with the effect of antagonist growth on the $\mathrm{pH}$ variation and the decrease in toxin concentration.

Of the five microorganisms that inhibited the growth of $F$. moniliforme, only the strain $\mathrm{S}_{1}$ Bacillus did not degrade the toxin, as the $\mathrm{FB}_{1}$ decreased $21.4 \%$ compared to the control. without inoculum that was degraded $31 \%$ (Table 2).

The high polarity of fumonisins probably induces spontaneous reaction of decomposition (Hirooka et al., 1993). This was observed during the maintenance of dried corn culture (Weibking et al., 1993), whose initial level of $298 \mu \mathrm{g} / \mathrm{g}$ was reduced to $230 \mu \mathrm{g} / \mathrm{g}$, during a storage period of six months at $-7^{\circ} \mathrm{C}$.

Table 1 - Inhibition of F.moniliforme $113 \mathrm{~F}$ by antagonic microorganisms isolated from corn and silage.

\begin{tabular}{|c|c|c|c|c|}
\hline \multirow[t]{2}{*}{ Microorganisms } & \multirow[t]{2}{*}{ Gram/Wirtz } & \multicolumn{2}{|c|}{ Inhibition zone $(\mathrm{mm})$} & \multirow[t]{2}{*}{ Origin } \\
\hline & & Whole culture & Crude extract & \\
\hline Bacillus S1 & Sporulated G+ & 72 & 52.5 & Silage \\
\hline Bacillus S9 & Sporulated G+ & 72.5 & 47.5 & Silage \\
\hline Bacillus S10 & Sporulated G+ & 70 & 39.5 & Silage \\
\hline Bacillus S69 & Sporulated G+ & 65 & 35 & Silage \\
\hline Yeast SE3071 & - & 50 & 25 & Corn \\
\hline
\end{tabular}

Table 2 - Degradation of $\mathrm{FB}_{1}(\mu \mathrm{g} / \mathrm{g})$ by corn and silage microorganisms.

\begin{tabular}{ccccccc}
\hline Time (days) & \multicolumn{7}{c}{ Microorganisms } \\
\cline { 2 - 7 } & S1 & S9 & S10 & S69 & SE3071 & CONTROL \\
\hline 0 & 230 & 230 & 230 & 230 & 230 & 230 \\
2 & $*$ & 197.64 & 136.15 & 135.22 & 166.27 & - \\
4 & $*$ & 155.91 & 122.93 & 127.66 & 162.46 & - \\
6 & 180.67 & 131.3 & 119.19 & 38.72 & 131.80 & 156.66 \\
\hline
\end{tabular}

- Interferents in the extract.

Table 3 - pH Variation in a period of six days. 


\begin{tabular}{ccccc} 
& Day 0 & Day 2 & Day 4 & Day 6 \\
\hline S1 & 7.5 & 7.2 & 7.9 & 8.3 \\
S9 & 6.7 & 7.2 & 8.3 & 8.6 \\
S10 & 6.9 & 7.2 & 7.7 & 8.1 \\
S69 & 6.9 & 7.3 & 8.0 & 7.7 \\
SE3071 & 5.9 & 6.5 & 7.4 & 6.8 \\
CONTROL & 6.8 & 6.8 & 6.8 & \\
\hline
\end{tabular}

The strains S9, S10, S69 and SE3071 showed promising results for $\mathrm{FB}_{1}$ degradation, causing decreases of $43,48,83$ and $57 \%$, respectively. In Table 2 , data up to the $6^{\text {th }}$ day of the experiment are shown, since problems occurred with chromatogram interpretation, possibly caused by interference of microbial metabolism. Regarding the strain S1, problems with microbial contaminant interference were observed, which hindered the chromatogram interpretation after two days.

In the control treatment, the $\mathrm{pH}$ was maintained at 6.8, while in the assays inoculated with antagonistic microorganisms it increased gradually, suggesting an alkalization process as a result of microbial growth (Table 3). After six days, the $\mathrm{pH}$ values varied from 7.7 to 8.6. Probably, the release of $\mathrm{C}_{2}$ amino group from the backbone of fumonisin molecule played significant role in the detoxification process, being the $\mathrm{pH}$ determination, a suitable parameter for monitoring biological degradation. (Jackson et al., 1996).

Although the literature reports increasing number of chemical detoxification processes, with emphasis on the adsorption using multifunctional chelating agents (Galvano et al., 1997; Park et al., 1997), there are still doubts regarding the negative effect on nutritional and commercial value of a chelate adsorbed products. Emphasis should be given to the promising potential of strain S69, which showed an antagonistic activity associated with detoxification twice more effective than the other microorganisms. The strain $\mathrm{S}_{1}$ was not very effective in grain detoxification, but it could still be used in the field, with the intention to control diseases caused by $F$. moniliforme, since it showed the largest inhibition zone, in terms of stability of the compound secreted (Table 1).

The fumonisins degradation by the selected microorganisms is an interesting method, since nowadays there is no effective procedure for the control of fumonisins produced at the final stage of the maturation process in corn.

\section{ACKNOWLEDGEMENTS}

The authors wish to thank CNPq and CPG-UEL for the financial resources and CAPES for the Master's scholarship to Simone B. Camilo.

\section{RESUMO}

A aplicação de microrganismos visando controle de fungos micotoxigênicos ou detoxificação em armazenagem consiste de uma área promissora, já que reduz contaminação de ecossistema por resíduos agrotóxicos. Visando controle biológico, microrganismos isolados de milho e silagem foram analisados perante efeito anti- $F$. moniliforme (linhagem 113F) em associação com a detoxificação de fumonisinas. Após análise de 150 isolados, selecionou-se quatro bacilos Grampositivos e uma levedura com melhor atividade inibitória. $\mathrm{O}$ halo de inibição variou de 50 a 72.5 $\mathrm{mm}$ usando culturas íntegras e 25 a $52.5 \mathrm{~mm}$, para extrato bruto de cultivo. Os isolados S9, S10, S69 (bacilos esporulados) e SE3071 (levedura) degradaram $43 \%, 48 \%, 83 \%$ e $57 \%$ de $\mathrm{FB}_{1}$ respectivamente, em relação à concentração inicial. $\mathrm{O} \mathrm{pH}$ aumentou gradativamente com o tempo de incubação.

\section{REFERENCES}

Bezuidenhout, G.C.; Gelderblom, W.C.A. ; GorstAllman, C.P.; Horak, R.M.; Marasas, W.F.O.; Spiteller, G. \& Vlegaar, R. (1988), Structure elucidation of the fumonisins, mycotoxins from Fusarium moniliforme. J. Chem. Soc. Chem. Commum., com.1476, 743-745 
Cawood, M.E.; Gelderblom, W.C.A.; Vlegaar, R.; Behrend, Y.; Thiel, P.G. \& Marasas, W.F.O. (1991), Isolation of the fumonisin mycotoxins: a quantitative approach. J. Agric. Food Chem., 39, 1958-1962

Galvano, F.; Pietri, A; Bertuzzi, T.; Bognanno, M.; Chies, L.; Angelis, A. \& Galvano, M. (1997), Activeted carbons: in vitro affinity for fumonisin $\mathrm{B}_{1}$ and relation of adsorption ability to physicochemical parameter. J. Food Protection, 60, 985-991

Gelderblom, W.C.A.; Kriek, N.P.J.; Marasas, W.F.O. \& Thiel, P.G. (1991), Toxicity and carcinogenicity of the Fusarium moniliforme metabolite, fumonisin $\mathrm{B}_{1}$, in rats. Carcinogenesis, 12, 1247-1251

Gelderblom, W.C.A.; Marasas, W.F.O.; Horak, R.M.; Vlegaar, R. \& Kriek, N.P.J. (1988), Fumonisins novel mycotoxins with cancer-promoting activity produced by Fusarium moniliforme. Appl. Environ. Microbiol., 54, 1806-1811

Harrison, L.R.; Colvin, B.M.; Greene, J.T.; Newman, L.E. \& Cole, J.R.Jr. (1990), Pulmonary edema and hydrotorax in swine produced by fumonisin $\mathrm{B}_{1}$, a toxic metabolite of Fusarium moniliforme. J. Vet. Diagn. Invest., 2, 217-221

Hirooka, E.Y.; Yamagushi, M.M.; Aoyama, S.; Sugiura, Y \& Ueno, Y. (1996), The natural occurrence of fumonisins in Brazilian corn kernels. Food Add. Contaminants, 13, 173-183

Kashiwagi, T.; Kunishima, N.; Suzuki, C.; Tsuchiya, F.; Nikkumi, S.; Arata, Y \& Morikawa, K. (1997), The novel acidophilic structure of the killer toxin from halotolerant yeast demonstrates with a fungal killer toxin. Structure .5, 81-94

Marasas, W.F.O.; Kellerman, T.S.; Gelderblom, W.C.A.; Coetzer, J.A.W.; Thiel, P.G. \& Van der Lugt, J.J. (1988), Leukoencephalomalacia in a horse induced by fumonisin $\mathrm{B}_{1}$ isolated from Fusarium moniliforme. Onderstepoort J. Vet. Res., 55,197-203

Marasas, W.F..O; Nelson, P.E. \& Tousson, T.A. (1984), Toxigenic species of Fusarium: Identity and mycotoxicology: Pennsylvania State University Press, pp.216-246

Motomura, M. (1995), Triagem e isolamento de microrganismos produtores de substâncias antimicrobianas e sua aplicação no controle de Fusarium moniliforme. Tese de Mestrado, Universidade Estadual de Londrina, Paraná, Brasil, pp.94

Motomura, M.; Lourenço, C.E.; Venturini, D.; Ueno, Y. \& Hirooka, E.Y. (1996), Screening and isolation of anti-Fusarium moniliforme compounds producing microorganisms from soil and corn. Rev. Microbiologia, 27, 213-217

Norred, W.P. (1993), Fumonisins-mycotoxins produced by Fusarium moniliforme. J. Toxicol. Environ. Health, 38, 309-328
Oliveira, A. S. (1995), Desenvolvimento de inoculante para fermentação lática de silagens: utilização de resíduos agroindustriais. Tese de Doutorado, Universidade Estadual de Londrina, Paraná, Brasil

Ono, E.Y.S.; Hara, L.D.; Sasaki, E.Y.; Ono, M.A; Funo, F.Y.; Hashimoto, E.H.; Vizoni, E. \& Hirooka, E.Y. (1998), Significado estatístico de micoflora durante a armazenagem de milho com $11 \%$ e $14 \%$ de umidade. Congresso Brasileiro de Ciência e Tecnologia de Alimentos, 16; Rio de Janeiro. Anais... Rio de Janeiro: SBCTA, 2, 1022-1025

Park, D.L; Garcia-Lopes, R.; Trujillu-Preciado, S. \& Price, R.L (1997), Reduction of risks associated with fumonisin contamination in corn. In: Fumonisins in Food, Advances in Experimental Medicine and Biology, 392, pp.335-344

Rheder, J.P.; Marasas, W.F.O.; Thiel, P.G.; Sydenham, E.W.; Shephard, G.S.\& van Schalkwyk, D.J. (1992), Fusarium moniliforme and fumonisins in corn in relation to human esophageal cancer in Transkei. D.J. Phytopathologia, 82, 353-357

Shephard, G.S.; Sydenham, E.W.; Thiel, P.G. \& Gelderblom, W.C.A (1990), Quantitative determination of fumonisin $\mathrm{B}_{1}$ and $\mathrm{B}_{2}$ by high performance liquid chromatography with fluorescence detection. J. Liq. Chromatography, 13, 2077-2087

Sydenham, E.W.; Shephard, G.S.; Thiel, P.G.; Marasas, W.F.O. \& Stockenstrtrom, S. (1991), Fumonisin contamination of commercial corn-based human foodstuffs. J. Agric. Food Chem., 39, 2014-2018

Sydenham, E.W.; Thiel, P.G.; Marasas, W.F.O.; Shephard, G.S.; Van Schalkwyk, D.J. \& Koch, K.R. (1990), Natural occurrence of some Fusarium mycotoxins in corn from low and high esophageal cancer prevalence areas of the Transkei, Southern Africa. J. Agric. Food Chem., 38, 1900-1903

Sydenham, E.W.; Van der Westhuizen, L.; Stockenstroem, S.; Shephard, G.S. \& Thiel, P.G. (1994), Fumonisin-contaminated maize: physical treatment for the partial descontamination of bulk shipments. Food Add. and Contaminants, 11, 25-32

Thiel, P.G.; Marasas, W.F.O.; Sydenham, E.W.; Shepard, G.S. \& Gelderblom, W.C.A (1992), Survey of fumonisin production by Fusarium species. Mycophatologia, 117, 3-9

Ueno,Y.; Aoyama, S.; Sugiura, Y.; Wang, D.S.; Lee, U.S.; Hirooka, E.Y.; Hara, S.; Karki, T.; Chen, G. \& Yu, S.Z. (1993), A limited surveys of fumonisins in corn and corn-based products in Asian Countries. Mycotoxin Research, 9, 27-34

Walker, G.M; Mcleod, A. H. \& Hodgson, V.J. (1995), Interactions between killer yeast and pathogenic fungi. FEMS Microbiol. Letters, 127, 213-222

Wang, D.S.; Liang, Y.X.; Iijima, K.; Sugiura, Y.; Tanaka, T.; Chen, G., Yu, S.Z \& Ueno, Y. (1995), Co-contamination of mycotoxins in corn harvested in 
Haimen, a high risk area of primary liver cancer in China. Mycotoxins, 41, 67-70

Weibking, T.S.; Ledoux, D.R.; Bermudez, A.J.; Turk, J.R. \& Rottinghaus, G.E. (1993), Effects of feeding Fusarium moniliforme culture material, containing know levels of fumonisin $\mathrm{B}_{1}$, on young broiler chick. Poult. Science, 72, 456-466

Received: September 21, 1998; Revised: February 12, 1999; Accepted: November 12, 1999. 